\title{
The venomous components in the worker and queen honey bees during their maturation and the seasonal generation
}

\author{
Hideo Inoue, $\left.{ }^{*}, 1\right)$,3) Terumi Nakajima ${ }^{2), 4)}$ and Ichiji Okada ${ }^{1)}$ \\ 1) Laboratory of Entomology, Faculty of Agriculture, Tamagawa University, \\ Machida, Tokyo 194, Japan \\ "Division of Molecular Biology, Institute for Medical and Dental Engineering, Tokyo Medical \\ and Dental University, Kanda-Surugadai, Chiyoda-ku, Tokyo 101, Japan
}

(Received: November 15, 1986)

Key words: Apis mellifera, worker bee, queen bee, apamin, melittin, MCD-peptide.

\begin{abstract}
Compositions of the venomous principles in worker and queen honey bees (Apis mellifera) during their maturation were examined in two criteria by the pattern analysis of electrophoresis and that of high performance liquid chromatography. The renom of well matured worker bee showed electrophoretically 13 proteinous bands including those corresponding to phospholipase $\mathrm{A}_{2}$, melittin, apamin and MCD-peptide. On the other hand, in the queen bee venom, the band corresponding to MCD-peptide was not detected but the two additional unknown components were found. The amounts of the venomous components in both worker and queen bee venoms increased remarkably within 14 days after eclosion.
\end{abstract}

\section{INTRODUCTION}

The venom of honey bee consists of various kind of amines, peptides and enzymes (Habermann, 1972). Catecholamines such as dopamine and noradrenaline, and histamine are known as the major biogenic amines in the renom. Hemolytic peptide (melittin), mast cell degranulating peptide (MCD-

* To whom correspondence should be addressed.

3) Present address: Minophagen Research Laboratory, Minophagen Pharmaceutical Co., 2-5233, Komatsubara, Zama, Kanagawa 228, Japan. 井上秀雄：(現住所）ミノファーダン製薬研究䜣 (开228 神䒬川県座間术小松原 2-5233)

4) Department of Analytical Chemistry, Faculty of Pharmaceutical Sciences, University of Tokyo, Bunkyo-ku, Tokyo 113, Japan.

中鴻暉躬：(現住所) 東京大学薬学部薬品分析化学 教室（干112 東宗都文京区本郷 7-3-1)

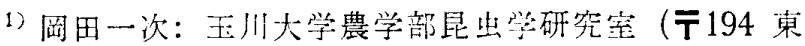
京静町时枋王川学園 6-1-1) peptide) and a sort of neurotoxin (apamin) are well known as peptidergic toxins in the venom. Phospholipase $\mathrm{A}_{2}$ and hyaluronidase are characterized as the representative enzymes in the venom. Some of these venomous components were reported to be varied during the maturation of bees after emergence (Bachmayer et al., 1972; Owen et al., 1977; Owen, 1979; Owen and Bridges, 1982). The most of the previous papers were based on the discontinuous observation of bee society and also little was known about queen bee venom (Bachmayer et al., 1972; Marz et al., 1981; Owen et al., 1977, Owen 1979).

We examined the venomous components of the worker and queen bees with respect to continuous observation during the adult maturation and the seasonal variation through spring to autumn.

\section{Materials and Methods}

Worker and queen bees. Honey bees used 
in this experiment were the Italian strain kept in Tamagawa University. Newly emerged worker bees $(0-24 \mathrm{hr}$ old $)$ were marked with colour paints, then put back to the normal colony and were collected again when required. Queen bees were raised according to the Doolitle method with the grafting of the first $17 \mathrm{hr}$ larvae. Two days before emergence, each queen cell was transferred to the mating hive which could be observed daily and taken out when required. Collected bees were stored at $-50^{\circ} \mathrm{C}$ temporarily and the venom sac was dissected out and lyophilized before analysis.

Preparation of the venom samples. A dried venom sac was homogenized with $50 \mu \mathrm{l}$ of $5 \%$ acetonitrile or $50 \mu \mathrm{l}$ of $20 \%$ sucrose solution for the analysis of peptides or enzymes, and with $50 \mu \mathrm{l}$ of $5 \%$ trichloroacetic acid (TCA) or $50 \mu$ l of $3 \%$ perchloric acid for analysis of catecholamines and polyamines. The homogenates were centrifuged at $3,000 \mathrm{rpm}$ for $5 \mathrm{~min}$. Each supernatant was analyzed directly by polyacrylamide gel electrophoresis (PAGE) or high performance liquid chromatography (HPLC).

Chemicals and standard materials. All chemicals and organic solvents used in this analysis were the guaranteed regent grade or HPLC grade respectively. Melittin, MCDpeptide and apamin were kindly provided by Professor $\mathrm{H}$. Yoshida, Hiroshima University School of Medicine.

Disc and slab polyacrylamide gel electrophoresis (PAGE). The separation of proteinous components in the venom was achieved by PAGE according to the technique modified from that of Benton and Patton (1965), using the disc $(17 \%)$ and slab (20\%) gel. The sample of 20-50 $\mu$ l was run from the anode to the cathode with a current density of $5 \mathrm{~mA}$ per tube for $75 \mathrm{~min}$ (disc) and a current density of $2.5 \mathrm{~mA}$ per gel for $4 \mathrm{hr}$ (slab). The polyacrylamide gels were stained with $1 \%$ amideblack $10 \mathrm{~B}$ and destained with $7 \%$ acetic acid. The standard peptides were also run along the samples and the protein patterns were determined by a densitometer in absorbance at $560 \mathrm{~nm}$. Ten individual bees were analyzed in each age.

High performance liquid chromatography (HPLC). Melittin, phospholipase $\mathbf{A}_{2}$, active amines in the venom were also separated by the reverse phase chromatography with a HPLC (Hitachi Model 655 or Jasco Tri Rotor II). For separation of melittin and apamin, a column of LS-410 ODS $(4 \times 300$ $\mathrm{mm}$, Toyo Soda) was used. The mobile phase was the phosphate buffer $(10 \mathrm{~mm}$ $\mathrm{KH}_{2} \mathrm{PO}_{4}, 50 \mathrm{~mm} \mathrm{Na}_{2} \mathrm{SO}_{4}, \mathrm{pH} 2.5$ ) with a linear gradient of $\mathrm{CH}_{3} \mathrm{CN}$ from 5 to $60 \%$ $(\mathrm{v} / \mathrm{v})$ over $30 \mathrm{~min}$ at a flow rate of $1 \mathrm{ml} / \mathrm{min}$ and with column temperature of $70^{\circ} \mathrm{C}$. Other elution systems were also used, i.e., Li-Chrosorb RP-8 ( $4 \times 250 \mathrm{~mm}$, Merck) with phosphate buffer ( $\mathrm{pH} 2.5$ ) containing $9.8 \%$ $\mathrm{CH}_{3} \mathrm{CN}$ for apamin and MCD-peptide; Zorbax-ODS $(4.6 \times 150 \mathrm{~mm}$, Dupon $)$ with phosphate buffer ( $\mathrm{pH} 2.5$ ) containing $30 \%$ $\mathrm{CH}_{3} \mathrm{CN}$ for phospholipase $\mathrm{A}_{2}$; Sil- $\mathrm{C}_{18}(4.6 \times$ $250 \mathrm{~mm}$, Jasco) with phosphate buffer $(0.1 \mathrm{M}$ $\mathrm{KH}_{2} \mathrm{PO}_{4}, \mathrm{pH} 2.0$ ) containing $3 \% \mathrm{CH}_{3} \mathrm{CN}$ as the mobile phase a flow rate of $1 \mathrm{ml} / \mathrm{min}$ at room temperature for catecholamines. Peptides and enzymes were monitored by UV absorbance at 210 or $220 \mathrm{~nm}$. Catecholamines and serotonin were monitored by their natural fluorescence (ex. $280 \mathrm{~nm}$, em. $315 \mathrm{~nm}$ ). Polyamines, histamine and serotonin were also analyzed by ion exchange HPLG monitoring with the OPA method using a column of IEX $210(4 \times 50 \mathrm{~mm}$, Toyo Soda) according to Yoshida et al. (1978). Peptides, enzymes and amines in the venom extracts were identified by the comparison of their retention time with those of the standard materials, and were determined by peak height.

\section{Results and Discussion}

The proteinous components in worker and queen bee venom

General aspects on the difference of the proteinous components between the venom of worker and queen bees were investigated by the electrophoretic patterns. The proteinous components were separated by PAGE and the patterns of both bee venoms were compared with those of the standard compounds such as phospholipase $\mathrm{A}_{2}$, melittin, apamin and MCD-peptide. Confirmation of those components was also performed by comparing the retention time with their standards by HPLC, after extracting each 


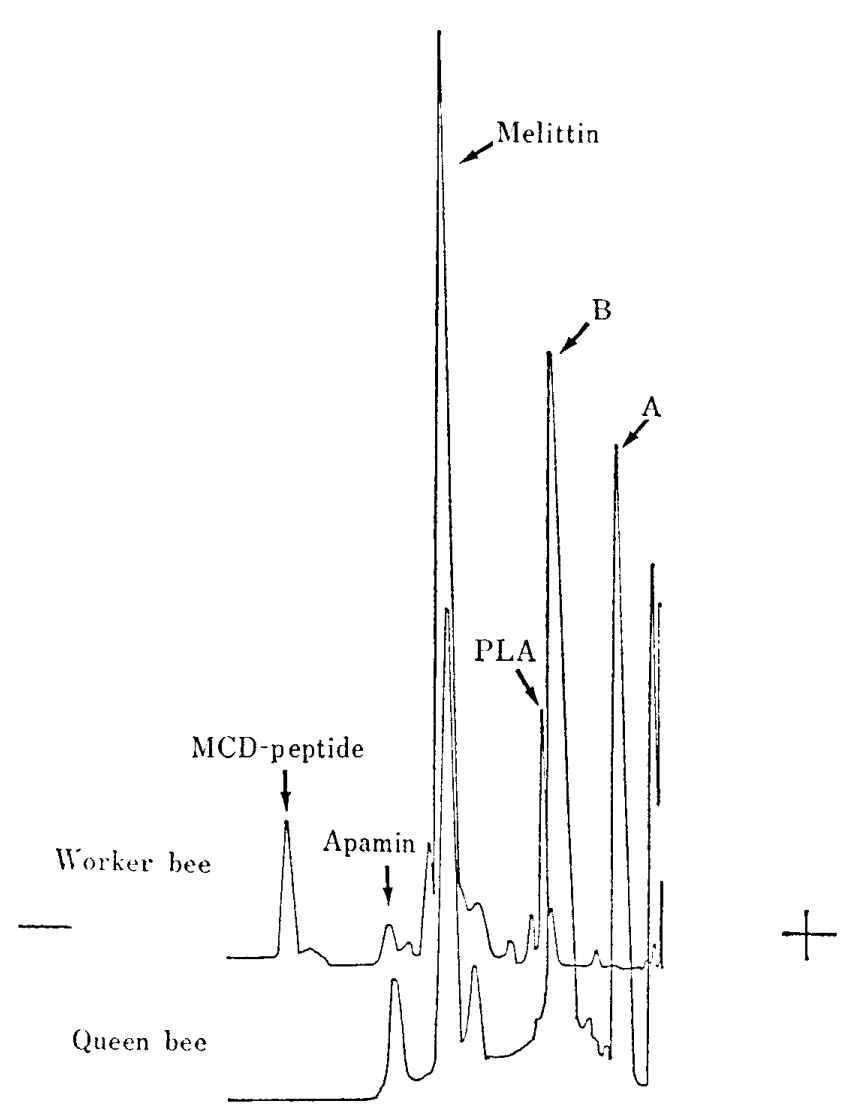

Fig. 1 Representative slab electrophoretic patterns of worker and queen bee venoms. The pattern corresponding to worker bee was obtained by use of one-half of a worker venom, whereas that marked with queen bee was obtained with a quarter of one queen venom.

band from the slab gels.

A marked difference was observed between worker and queen bee venom components. As shown in Fig. 1, the venom of foraging bee ( 21 days old) was consisted of 13 bands including well recognized common components like phospholipase $\mathrm{A}_{2}$, melittin, apamin and MCD-peptide. Melittin was a major component and the others were the minor ones as reported by many papers (Banks and Shipolini, 1986; Shipolini, 1984). In contrast to this, in the mated queen bee (1 year old) venom, two major components ( $\mathrm{A}$ and $\mathrm{B}$ ) stained by amide black dye were less migrated than melittin but unidentified. The content of melittin appeared to be the minor component and additionally a band corresponding to MCD-peptide was not detected in the venom through the life of queen bees, and this was also confirmed by the analysis by HPLC (data not presented).

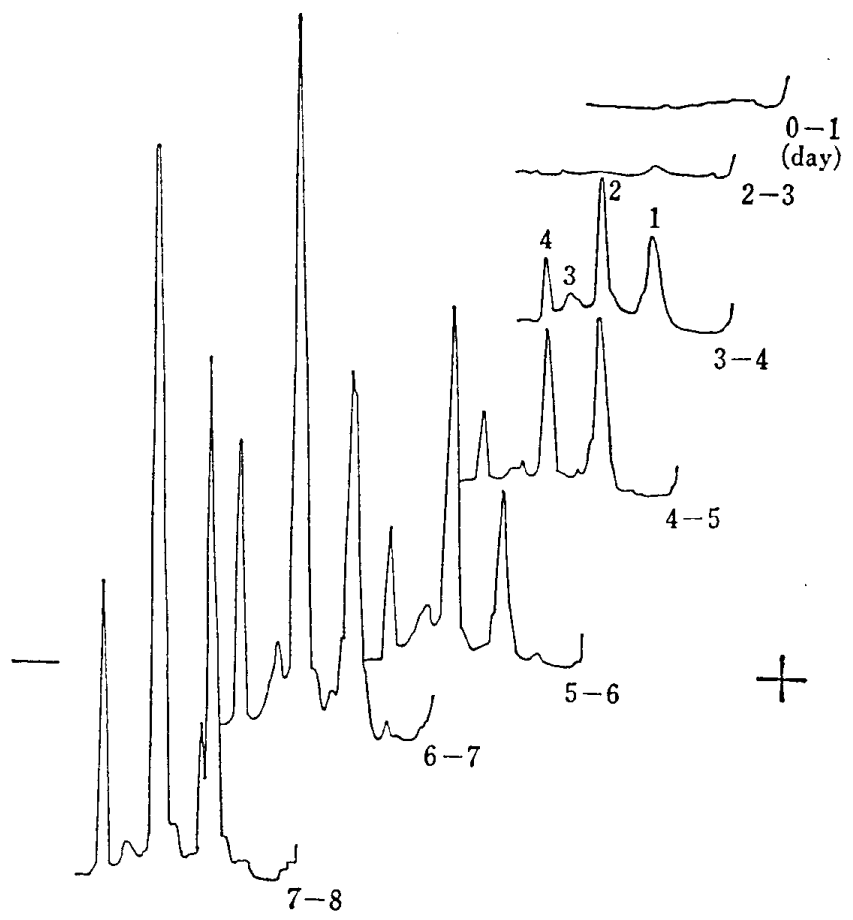

Fig. 2 Representative disc electrophoretic patterns of venom in worker bees with different age.

Each pattern indicates the amount of one worker venom. 1, phospholipase $A_{2} ; 2$, melittin; 3, apamin; 4, MCD-peptide. Age: days after emergence.

These results confirm the finding of Marz et al. (1981) that the queen bee venom was different from the worker bee venom. It seems likely that the venom system is related to the cast development of worker and queen bees, and that MCD-peptide can be considered as a criterion of cast differentiation.

Age dependent changes of the venom compositions in the worker and queen bee venom

PAGE patterns showed the changes of proteinous components in the worker venom with different age (Fig. 2). Any proteinous band was not observed in the bees aged 1 day after emergence but the bands corresponding to phospholipase. $\mathrm{A}_{2}$, melittin, apamin and MCD-peptide were observed in the 3-day-old bees. Peptides, biogenic amines and enzymes in the worker venom were determined in various ages of bees during the period from April to December (Tables 1 and 2). Presence of serotonin has been recognized in the venom gland (Grzycki and Czerny, 1973) and the sting apparatus 
Table 1 Peptide and enzyme contents in the venom sac of worker bees.

\begin{tabular}{|c|c|c|c|c|c|}
\hline & $\begin{array}{c}\text { Age of bee } \\
\text { (days) }\end{array}$ & Apamin & Melittin & MCD & PLA \\
\hline \multirow[t]{5}{*}{ May-June } & $0-1$ & - & - & - & - \\
\hline & $7-8$ & $4.9 \pm 0.6$ & $87 \pm 23.4$ & $3.9 \pm 0.3$ & $31.1 \pm 16.4$ \\
\hline & $14-15$ & $5.4 \pm 0.2$ & $249 \pm 18.0$ & $4.3 \pm 0.9$ & $55.2 \pm 7.5$ \\
\hline & $21-22$ & $6.1 \pm 0.9$ & $267 \pm 23.0$ & $4.7 \pm 1.4$ & $71.2 \pm 27.3$ \\
\hline & $28-29$ & $8.1 \pm 2.0$ & $296 \pm 44.0$ & $6.1 \pm 3.0$ & $38.2 \pm 12.4$ \\
\hline \multirow[t]{6}{*}{ June-July } & $0-1$ & - & - & - & - \\
\hline & $7-8$ & $4.0 \pm 0.2$ & $174 \pm 29.0$ & $3.0 \pm 0.5$ & $29.8 \pm 18.1$ \\
\hline & $14-15$ & $4.3 \pm 2.0$ & $296 \pm 68.0$ & $3.7 \pm 1.3$ & $69.9 \pm 22.9$ \\
\hline & $21-22$ & $7.7 \pm 0.3$ & $279 \pm 87.0$ & $6.3 \pm 0.4$ & $32.4 \pm 9.8$ \\
\hline & $28-29$ & $7.3 \pm 2.6$ & $397 \pm 14.9$ & $6.8 \pm 1.8$ & \\
\hline & $35-36$ & $8.4 \pm 1.7$ & $388 \pm 55.0$ & $6.3 \pm 1.5$ & $37.0 \pm 12.6$ \\
\hline \multirow[t]{10}{*}{ Aug.-Oct. } & $0-1$ & - & - & - & - \\
\hline & $7-8$ & $3.0 \pm 1.3$ & $42 \pm 50.6$ & $2.1 \pm 0.3$ & $14.2 \pm 1.3$ \\
\hline & $14-15$ & $3.1 \pm 1.3$ & $105 \pm 21.1$ & $2.7 \pm 0.4$ & $18.9 \pm 4.1$ \\
\hline & $21-22$ & $5.3 \pm 1.2$ & $166 \pm 55.5$ & $4.5 \pm 0.8$ & $34.8 \pm 7.2$ \\
\hline & $28-29$ & $5.7 \pm 1.3$ & $197 \pm 98.0$ & $3.7 \pm 1.3$ & $25.5 \pm 13.6$ \\
\hline & $35-36$ & $5.2 \pm 0.4$ & $270 \pm 131$ & $4.1 \pm 1.2$ & \\
\hline & $42-43$ & $5.2 \pm 1.3$ & $244 \pm 100$ & $5.0 \pm 1.0$ & \\
\hline & $48-49$ & $5.7 \pm 0.6$ & $327 \pm 41.0$ & $5.2 \pm 1.2$ & \\
\hline & $56-57$ & $6.6 \pm 0.4$ & $243 \pm 24.2$ & $5.3 \pm 1.1$ & \\
\hline & $62-63$ & $4.4 \pm 0.9$ & $180 \pm 43.0$ & & \\
\hline \multirow[t]{4}{*}{ Nov.-Dec. } & $0-1$ & - & - & & \\
\hline & $7-8$ & $1.6 \pm 0.2$ & $82 \pm 27.1$ & & \\
\hline & $14-15$ & $3.1 \pm 0.8$ & $126 \pm 71.0$ & & \\
\hline & $21-22$ & $2.8 \pm 0.6$ & $160 \pm 43.0$ & & \\
\hline
\end{tabular}

The contents are expressed as $\mu \mathrm{g} / \mathrm{sac} \pm$ S.D. $(n=3) . \quad \mathrm{MCD}$, mast cell degranulating peptide; PLA, phospholipase $\mathbf{A}_{2}$. - not detected.

(Welsh and Moorhead, 1960), but the presence has been doubted in the venom itself. However, we confirmed that serotonin was not detectable in the venom sac but really was in the venom collected by a capillary tube from the sac of foraging bee (unpublished). Putrescine, spermidine and spermine were recently recognized as the aminergic component as well as histamine in Hymenopteran venom (Nakajima et al., 1983), but spermidine and spermine which are the minor amines in the worker venom were irregularily detected during May to December.

Each venomous component of worker bees was poor in content within 1 day after emergence but increased rapidly up to 14 days. Histamine was known to be low content in the emerged bees and to increase with age
(Owen et al., 1977). Histamine, dopamine, putrescine and spermidine were detectable in worker bees before emergence (Table 2). It is interesting that serotonin appeared in the bees approximately aged 14 days when they are in the transition stage from nurse bee to foraging bee. Dopamine level raised early to a maximum and then fell in older bees. These individual data indicated that, in the venom producing system, the maximal level of each compound reached in different period. Owen and Bridges (1982) have stated that there were age dependent variation and seasonal differentiation in the quantities of dopamine and noradrenaline. Seasonal changes in the peptides showed that the bees from May to July contained a high level of those peptides. This might be 
Table 2 Amine contents in the venom sac of worker bees.

\begin{tabular}{|c|c|c|c|c|c|c|c|c|c|c|}
\hline & $\begin{array}{l}\text { Age of bee } \\
\text { (days) }\end{array}$ & $\mathrm{His}$ & & $\mathrm{DA}$ & & $\mathrm{Nad}$ & $5 \mathrm{HT}$ & Put & Spd & Spm \\
\hline \multirow[t]{5}{*}{ May-June } & $0-1$ & $6 \pm$ & 0.7 & $27 \pm$ & 15 & $1 \pm 0.2$ & - & $122 \pm 20$ & $9.1 \pm 3.7$ & - \\
\hline & $7-8$ & $375 \pm$ & 150 & $960 \pm$ & 388 & $48 \pm 47$ & - & $207 \pm 79$ & $8.2 \pm 4.4$ & - \\
\hline & $14-15$ & $892 \pm$ & 306 & $1,296 \pm$ & 680 & $139 \pm 56$ & $2.9(1)$ & $378 \pm 236$ & $9.5 \pm 3.5$ & $486(1)$ \\
\hline & $21-22$ & $1,736 \pm$ & 402 & $449 \pm$ & 257 & $314 \pm 78$ & $10.5 \pm 1.5$ & $728 \pm 309$ & $29.4 \pm 17.3$ & $61(1)$ \\
\hline & $28-29$ & $1,355 \pm$ & 161 & $633 \pm$ & 299 & $643 \pm 389$ & $12.5 \pm 0.7$ & $1,020 \pm 580$ & $23.0 \pm 12.2$ & - \\
\hline \multirow[t]{7}{*}{ June-July } & -1 & $4 \pm$ & 0.1 & $13 \pm$ & 5 & - & - & $84 \pm 24$ & $11.8 \pm 9.6$ & - \\
\hline & $0-1$ & $13 \pm$ & 4 & $26 \pm$ & 3 & - & - & $51 \pm 5$ & $4.0 \pm 9.6$ & $15(1)$ \\
\hline & $7-8$ & $176 \pm$ & 151 & $364 \pm$ & 40 & $13 \pm 13$ & - & $103 \pm 69$ & $5.6 \pm 2.3$ & $3(1)$ \\
\hline & $14-15$ & $1,349 \pm$ & 511 & $825 \pm$ & 480 & $356 \pm 328$ & $14.3 \pm 7.8$ & $395 \pm 199$ & $29.3 \pm 16.9$ & $5(1)$ \\
\hline & $21-22$ & $976 \pm$ & 700 & $170 \pm$ & 125 & $396 \pm 300$ & $16.0 \pm 11.5$ & $514 \pm 164$ & $39.5 \pm 20.2$ & $11 \pm 7$ \\
\hline & $28-29$ & $2,143 \pm$ & 356 & $314 \pm$ & 212 & $273 \pm 151$ & $14.7(2)$ & $435 \pm 89$ & $12.8 \pm 10.4$ & $81 \pm 61$ \\
\hline & $35-36$ & $1,525 \pm$ & 349 & $816 \pm 1$ & 175 & $541 \pm 157$ & $14.9 \pm 2.1$ & $541 \pm 156$ & $20.1 \pm 2.9$ & $116(1)$ \\
\hline \multirow[t]{10}{*}{ Aug.-Oct. } & $0-1$ & $4 \pm$ & 3 & $44 \pm$ & 41 & $3 \pm 0.5$ & - & $164 \pm 53$ & - & - \\
\hline & $7-8$ & $644 \pm$ & 180 & $1,558 \pm 1$ & 224 & $26 \pm 19$ & - & $121 \pm 13$ & - & - \\
\hline & $14-15$ & $1,506 \pm$ & 245 & $1,568 \pm 1$ & 183 & $61 \pm 17$ & $3.6(1)$ & $268 \pm 114$ & - & - \\
\hline & $21-22$ & $2,133 \pm$ & 270 & $1,342 \pm 1$ & 340 & $71 \pm 72$ & $3.5(1)$ & $396 \pm 252$ & - & - \\
\hline & $28-29$ & $2,231 \pm$ & 285 & $1,687 \pm 1$ & 240 & $342 \pm 73$ & $11.5 \pm 6.2$ & $364 \pm 32$ & - & - \\
\hline & $35-36$ & $2,944 \pm$ & 764 & $1,616 \pm$ & 650 & $354 \pm 125$ & $24.1 \pm 2.7$ & $683 \pm 331$ & - & - \\
\hline & $42-43$ & $1,794 \pm 1$, &, 359 & $2,035 \pm$ & 239 & $380 \pm 154$ & $15.3 \pm 3.7$ & $726 \pm 643$ & - & - \\
\hline & $49-50$ & $2,655 \pm$ & 517 & $392 \pm$ & 92 & $601 \pm 140$ & $18.0 \pm 12.8$ & $1,196 \pm 684$ & - & - \\
\hline & $56-57$ & $2,751 \pm$ & 105 & $1,051 \pm$ & 564 & $627 \pm 134$ & $28.2 \pm 14.1$ & $864 \pm 129$ & - & - \\
\hline & $63-64$ & $2,509 \pm$ & 470 & $934 \pm$ & 974 & $639 \pm 280$ & $21.1 \pm 5.3$ & $746 \pm 122$ & - & - \\
\hline \multirow[t]{4}{*}{ Nov.-Dec. } & $0-1$ & $48 \pm$ & 29 & $260 \pm$ & 224 & $8 \pm 20$ & - & $111 \pm 5$ & - & - \\
\hline & $7-8$ & $754 \pm$ & 207 & $2,348 \pm 1$ &, 232 & $82 \pm 27$ & $3.3 \pm 1.6$ & $193 \pm 66$ & - & - \\
\hline & $14-15$ & $678 \pm$ & 265 & $7,543 \pm 1$ & 053 & $183 \pm 116$ & $4.1 \pm 1.2$ & $222 \pm 37$ & - & - \\
\hline & $21-22$ & $1,142 \pm$ & 254 & $699 \pm$ & 412 & $186 \pm 94$ & $6.5 \pm 2.8$ & $146 \pm 81$ & - & - \\
\hline
\end{tabular}

The contents are expressed as ng/sac \pm S.D. $(n=3)$. Figuresin parentheses indicate the number of bees analyzed. His, histamine; DA, dopamine; Nad, noradrenaline; 5HT, serotonin; Put, putrescine; Spd, spermidine; Spm, spermine. - not detected.

due to the pollen consumption on which the bees fed in the hive, and or the pollen sources in the field.

Peptides and amines in the queen venom were analyzed at different age (Table 3 ). Queen bees in the first 14 days were nonfertilized but thereafter all of bees were fertilized. The queen bee was recognized to use her venom only to kill old queen and to overcome sibling rivals within hours of emergence (Butler, 1963). Melittin was detected in queen venom 2 days prior emergence, increased remarkably up to the first 14 days, then decreased gradually. Histamine content increased in accordance with age from -3 to 35 days. Owen et al. (1977) demonstrated that the histamine level in the queen venom reached to a maximum at about 6 weeks, and the hyaluronidase activity was the highest in bees aged 10 days after emergence (Owen, 1979). MCD-peptide was not detected and apamin was in less content in the queen venom while dopamine was a high level throughout the maturation stage. Those were the characteristic properties in the queen bee venom.

\section{Conclusion}

We found that venomous components in 
Table 3 Peptide and amine contents in the venom sac of queen bees.

\begin{tabular}{|c|c|c|c|c|c|c|}
\hline $\begin{array}{l}\text { Age of bee } \\
\text { (days) }\end{array}$ & Apamin* & Melittin* & DOPA $^{* *}$ & Dopamine** & $\mathrm{Nad}^{* *}$ & His** \\
\hline-3 & & & $20(2)$ & - & - & $8(2)$ \\
\hline-2 & - & $0.8 \pm 0.7$ & $31 \pm 2$ & - & - & $10 \pm$ \\
\hline-1 & - & $18 \pm 8$ & $27(1)$ & $4.0(1)$ & - & $66(1)$ \\
\hline $0-1$ & $0.5 \pm 0.2$ & $92 \pm 29$ & $51 \pm 54$ & $222 \pm$ & $54 \pm 18$ & $82 \pm$ \\
\hline $7-8$ & $1.1 \pm 0.8$ & $526 \pm 295$ & - & $10,084 \pm 1,767$ & $101 \pm 42$ & $4,841 \pm 1,711$ \\
\hline $14-15$ & $1.9 \pm 0.5$ & $737 \pm 379$ & - & $10,207 \pm 2,680$ & $488 \pm 263$ & $5,041 \pm 640$ \\
\hline $21-22$ & $1.6 \pm 1.2$ & $644 \pm 135$ & - & $15,268 \pm 11,569$ & $376 \pm 60$ & $7,389 \pm 1,628$ \\
\hline $28-29$ & $1.7 \pm 0.6$ & $571 \pm 108$ & - & $13,716 \pm 3,445$ & $227 \pm 33$ & $8,157 \pm \quad 722$ \\
\hline $35-36$ & $1.9 \pm 1.1$ & $416 \pm 96$ & - & $8,141 \pm 2,351$ & $155 \pm 88$ & $8,413 \pm 1,061$ \\
\hline
\end{tabular}

Means with standard deviations (S.D.) are based on $n=3$. Figures in parentheses indicate the number of bees analyzed. * Values are expressed as $\mu \mathrm{g} / \mathrm{sac} . \quad * *$ Values are expressed as ng/sac. - not detected.

the worker bees are different from those of the queen bees in which MCD-peptide is not detected. The present data suggests that the maturation of the worker venom would be coincided with the time of transition from nurse bee to foraging bee. Further investigations need to discuss the role of queen bee venom except for the fighting with other queens when she emerges, though the development of venom formation in the queen bee was confirmed to be proceeding through the first 14 days of life.

\section{Acknowledgements}

We are greatly indebted to Dr. Tadashi Yasuhara of Tokyo Medical and Dental University for his technical suggestions of chromatography, and Mr. Tadaharu Yoshida and Mr. Kazuo Takeuchi of Tamagawa University for their supports in obtaining queen bees. Thanks are also due to Prof. Hisanobu Yoshida of Hiroshima University for providing us the pure venom peptides as the standard.

\section{REFERENCES}

Bachmayer, H., G. Kreil and G. Suchanek (1972) : Synthesis of promelittin and melittin in the venom gland of queen and worker bees: Patterns observed during maturation. J. Insect Physiol., 18: 1515-1521.

Banks, B. E. C. and R. A. Shipolini (1986) : Chemistry and pharmacology of honey-bee venom. In: Venoms of Hymenoptera (ed., Piek, T.), pp. 329-416, Academic Press, London.

Benton, A. W. and R. L. Patton (1965): A qualitative analysis of the proteins in the venom of honey bees. J. Insect Physiol., 11: 13591364.

Butler, C. G. (1963): The honey-bee colonylife history. In: The Hive and the Honey Bee (ed., Grout, R. A.), pp. 35-70, Dadant and Sons, Hamilton, Illinois.

Grzycki, S. and K. Czerny (1973) : Cytochemical studies on the poison gland of honey-bee sting. Acta Anat., 82: 91-96.

Habermann, E. (1972): Bee and wasp venoms. Science, 177: 314-322.

Marz, R., C. Mollay and G. Kreil (1981): Queen bee venom contains much less phospholipase than worker bee venom. Insect Biochem., 11: $685-690$.

Nakajima, T., T. Yasuhara, N. Yoshida, Y. Takemoto, S. Shinonaga, R. Kano and H. Yoshida (1983): The pattern analysis of biologically active amines in some Hymenopteran venoms by high performance liquid chromatography. Jpn. J. Sanit. Zool., 34: 67-71.

Owen, M. D. (1979): Relationship between age and hyaluronidase activity in the venom of queen and worker honeybees (Apis mellifera L.). Toxicon, 17: 94-98.

Owen, M. D., J. L. Braidwood and A. R. Bridges (1977): Age dependent changes in histamine content of venom of queen and worker honey bees. J. Insect Physiol., 23: 1031-1035.

Owen, M. D. and A. R. Bridges (1982): Catecholamines in honey bee (Apis mellifera L.) and various vespid (Hymenoptera) venoms. Toxicon, 20: 1075-1084.

Shipolini, R. A. (1984): Biochemistry of bee venom. In: Handbook of Natural Toxins, Vol. 2 (ed., Tu, A. T.), pp. 49-85, Marcel Dekker, New York. 
Welsh, J. H. and M. Moorhead (1960): The quantitative distribution of 5-hydroxytryptamine in the invertebrates, especially in their nervous system. J. Neurochem., 6: 146-169.

Yoshida, H., T. Nakajima, Y. Ueno, N. Koine, M. Onda, K. Ohe and A. Miyoshi (1978): Simple and rapid screening method of amino acids and amines in biological samples. Hiroshima J. Med. Sci., 27: 85-92.

\section{摘 要}

日齢に伴うミッバチのハチ毒成分

働きバチ，女王バチの八チ毒成分の比較および日㱓 に伴う八チ毒成分の変化を, 電気泳動, 高速液体ク口 マトグラフィーにより調べた. 働きバチ毒は, フォス

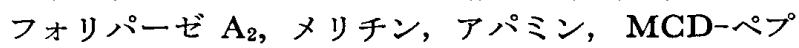
チドを含む13成分を泳動分析により確認した. 一方, 女王バチ毒では働きバチ毒の泳動パターンと異なり， MCD-ペプチドが認められず，また㗢きバチ毒にはみ られない未同定物質を検出した. 働きバチ，女王バチ とも日齢に伴い，出房後14日までに八チ毒成分が顕著 に増加することがわかった。 